\title{
A Rare Case of Non-resolving Pneumonia: Lipoid Pneumonia
}

\section{Geç Rezorbe Olan Pnömoninin Nadir Bir Nedeni: Lipoid Pnömoni}

\author{
๑ Bilge Yılmaz Kara, • Songül Özyurt, • Yavuz Metin*, • Dilek Karadoğan, • Ünal Şahin \\ Recep Tayyip Erdoğan University Faculty of Medicine, Department of Pulmonary Diseases, Rize, Turkey \\ ${ }^{*}$ Recep Tayyip Erdoğan Üniversitesi Faculty of Medicine, Department of Radiology, Rize, Turkey
}

Abstract

Lipoid pneumonia (LP) is defined as the sum of clinical and radiological abnormalities due to aspiration of oil based foreign materials. There are two kinds of LP defined in the literature. Exogenous LP is associated with aspiration of oily materials into the airways and the lung parenchyma consciously or accidentally as in fire-eater's lung. Endogenous LP is a more complicated situation that occurs when an endogenous lipoid material fills the alveolar space without a history of aspiration. It is associated with certain conditions like bacterial pneumonia. The pathogenesis is similar to alveolar proteinosis. We report a case of non-resolving pneumonia finally diagnosed as exogenous LP caused by aspiration of a liquid laxative.

Keywords: Non-resolving pneumonia, lipoid pneumonia, aspiration, laxatives
Lipoid pnömoni (LP) akciğere yağ bazlı sıvı aspirasyonu sonrası ortaya çıkan klinik ve radyolojik bir tablodur. Literatürde tanımlanmış iki tür LP mevcuttur. Ekzojen LP ateş yiyenlerde olduğu gibi yağlı maddenin hava yolları ve akciğer parankimine istemli olarak ya da kaza sonucu aspirasyonu ile oluşur. Endojen LP ise lipid yapıdaki endojen materyalin aspirasyon öyküsü olmaksızın alveoler boşlukları doldurması ile ortaya çıkan daha ciddi bir tablodur. Endojen LP bakteriyel pnömoni gibi bazı klinik durumlara eşlik eder. Patogenez alveolar proteinozla benzerdir. Burada rezorbe olmayan pnömoninin bir nedeni olarak laksatif aspirasyonuna bağlı ekzojen LP olgusu sunulacaktır.

Anahtar Sözcükler: Geç rezorbe olan pnömoni, lipoid pnömoni, aspirasyon, laksatifler

\section{Case}

A 25-year-old female patient was admitted to the hospital with a history of productive cough, dyspnea and loss of appetite for the last two weeks. She was disabled and bedridden due to cerebral palsy since birth. Her parents were responsible for her personal care. On admission, the physical examination revealed cachexia with a body mass index of $14.7 \mathrm{~kg} / \mathrm{m}^{2}$. Body temperature was $36.7{ }^{\circ} \mathrm{C}$, pulse rate was 86 per minute and arterial blood pressure was $110 / 70 \mathrm{mmHg}$. Chest auscultation revealed right-sided coarse crackles more prominent over the middle and lower lung zones. Examination of the abdomen was normal except diffuse tympanism. A chest radiograph showed non homogenous opacities compatible with pneumonia on the right lung field (Figure 1). Biochemical examination including acute phase reactants was normal. Oral clarithromycin added to intravenous ceftriaxone treatment was started with the diagnosis of community acquired pneumonia. During the hospital stay, the patient's nutritional status was evaluated. Her mother was feeding her orally with ordinary food in semi-liquid form. During these feeding episodes, occasional aspiration was observed by the health staff. After a weak gag reflex was observed during neurological examination, feeding through a nasogastric tube or gastrostomy tube was recommended but the parents refused. After five days of hospitalization, the patient was discharged with oral antibiotherapy. A control chest $\mathrm{X}$-ray obtained at the follow-up visit three weeks after discharge showed little or no change in the opacities. Aspiration episodes did not recur after discharge because the patient's caregivers were well educated to
Address for Correspondence/Yazışma Adresi: Bilge Yılmaz Kara, Recep Tayyip Erdoğan University Faculty of Medicine, Department of Pulmonary Diseases, Rize, Turkey Phone: +90 5052301664 E-mail: drbilgeyilmaz@hotmail.com ORCID: orcid.org/0000-0003-2690-4932 Received/Geliş Tarihi: 06 June 2019 Accepted/Kabul Tarihi: 29 October 2019

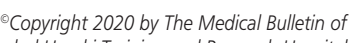
istanbul Haseki Training and Research Hospital The Medical Bulletin of Haseki published by Galenos Yayınevi. ${ }^{\circledR}$ Telif Hakkı 2020 istanbul Haseki Eğitim ve Araștırma Hastanesi Haseki Tıp Bülteni, Galenos Yayınevi tarafından yayınlanmıştır. 
avoid aspiration. Thoracic computed tomography (CT) revealed lung infiltrates on the posterior segments of both upper and lower lobes of the right lung (Figure 2). Bronchoscopic examination was normal with no

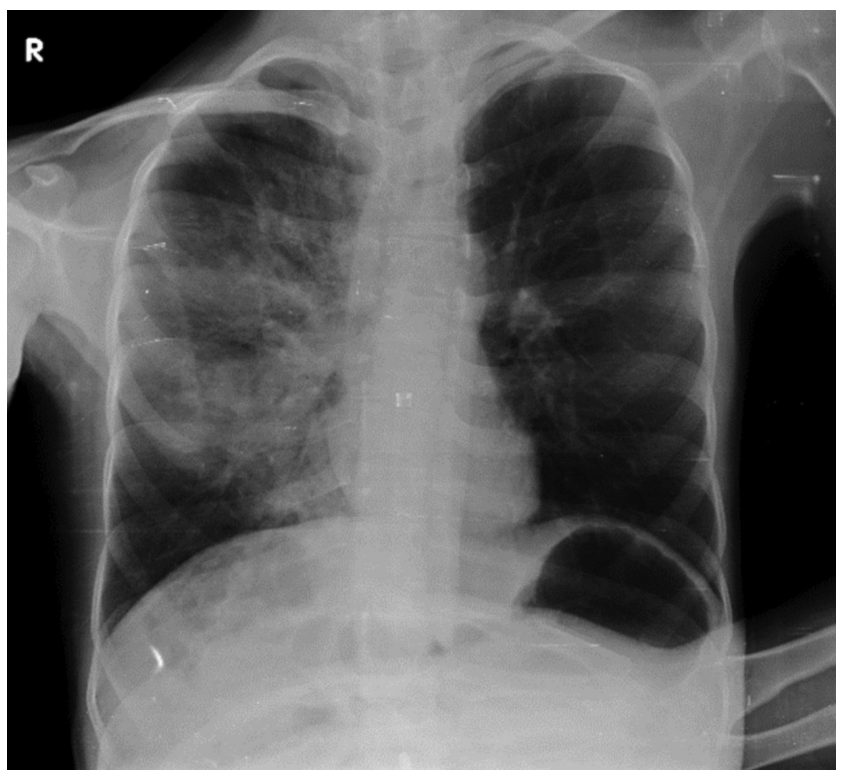

Figure 1. Chest $X$-Ray of the patient at initial examination showing infiltrates in the right lung
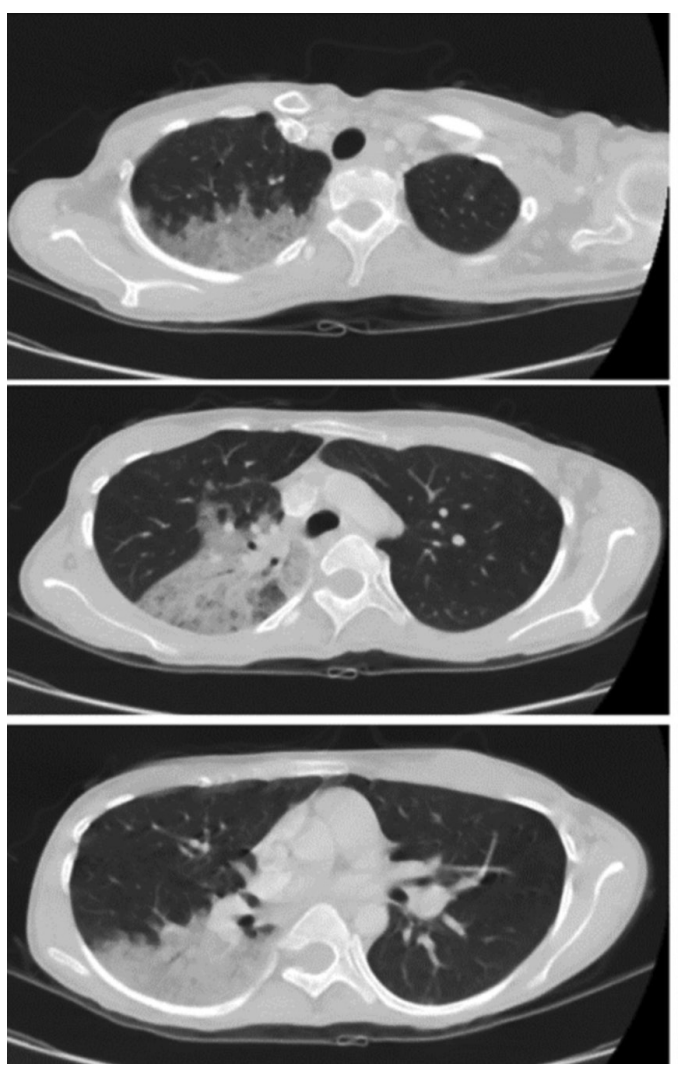

growth on aerobic cultures. Microscopic examination of the lavage fluid was negative for acid-resistant bacilli. A differential diagnosis of non resolving pneumonia was necessary; therefore, the medical history of the patient was deepened. Drug enquiry revealed long-term laxative use for chronic constipation. The clinical status of the patient was attributed to the use of oil-based laxative. Because of witnessed aspiration, a clinical diagnosis of lipoid pneumonia (LP) was made. The responsible laxative was ceased and the patient was scheduled for follow-up examinations.

Informed consent was obtained from the patient's family for this publication.

\section{Discussion}

While making a differential diagnosis of non-resolving pneumonia, patient characteristics must be taken into account. In young patients, benign diseases like tuberculosis and vasculitis are the most common reasons while malignancies like adenocarcinoma with lepidic pattern and interstitial lung disease are more prominent in the elderly. Patients with chronic comorbidities are more prone to have non resolving pneumonia caused by antibiotic-resistant bacteria. Bronchoscopic evaluation with bronchoalveolar lavage (BAL) and mucosal biopsy
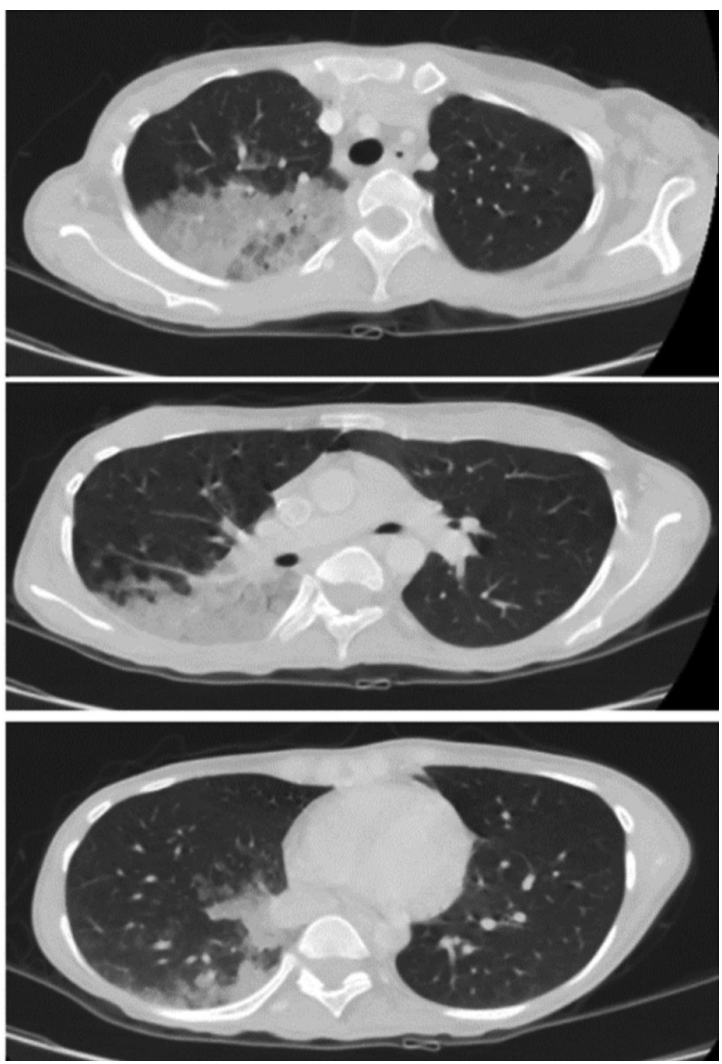

Figure 2. Thoracic computed tomography images obtained at the control visit 
are recommended while dealing with non-resolving pneumonia in order to rule out endobronchial pathologies (1). Sometimes only a more careful anamnesis and history taking may be adequate for making the diagnosis as it was in our case (2). In rare cases, sputum cytology may disclose the hidden pathology especially when examined by an experienced cytologist (3), but usually more invasive methods like parenchymal biopsy or necropsy are needed for definitive diagnosis (4).

Lipoid pneumonia is one of the rare diseases causing non-resolving pneumonia. Clinical features may vary depending on the amount of aspirated substance. It may present with clinical features ranging from no symptoms to severe respiratory failure. There is no specific finding or biochemical measurement recommended for LP diagnosis (5). Radiologic findings may include consolidation, ground glass opacities, crazy-paving pattern or mass-like lesions on thoracic CT (6). Cytology may demonstrate numerous lipid-laden macrophages that are positively staining with lipid dyes like Oil red O or Sudan black (7). There are no studies in the literature delineating the best therapeutic options for LP. Antibiotics and systemic corticosteroids as well as therapeutic lavage are recommended (8).

Diagnostic criteria for LP have been reported as follows:

- History of mineral oil or other oil product ingestion

- Compatible radiologic findings

- Presence of intra-alveolar lipids or lipid-laden macrophages on BAL analysis (8).

In our case, we could not show lipid-laden macrophages because there was no suspicion of LP among the differential diagnoses before bronchoscopy. In the absence of a responsible substance or factor highlighted by detailed history taking, the presence of lipid laden macrophages may not be adequate for a precise diagnosis. This underlines the need for a good history in aiding with a focused diagnosis and to help provide prompt treatment (9).

In conclusion; LP is a relatively uncommon disease causing non-resolving pneumonia. It may mimic more common diseases such as pneumonia, pulmonary fibrosis, and lung cancer. It should be considered a potential diagnosis in patients with non-resolving pneumonia when a proper treatment does not yield expected clinical response.

\section{Authorship Contributions}

Concept: B.Y.K., S.Ö., D.K. Design: B.Y.K. Data Collection or Processing: B.Y.K. Analysis or Interpretation: B.Y.K., Y.M., Ü.Ş. Literature Search: B.Y.K. Writing: B.Y.K.

Conflict of Interest: No conflict of interest was declared by the authors.

Financial Disclosure: The authors declared that this study received no financial support.

\section{References}

1. Chaudhuri AD, Mukherjee S, Nandi S, Bhuniya S, Tapadar SR, Saha M. A Study on Non-Resolving Pneumonia with Special Reference to Role of Fiberoptic Bronchoscopy. Lung India 2013;30:27-32.

2. Simons SO, Braam EAJE, de Boer RC, Looijen-Salamon M, Heijdra YF. Non-resolving pneumonia in patient with obsessive-compulsive disorder. Thorax 2014;69:193.

3. Hanrahan L, Chotirmall SH, Nicholson S, O'Riordan D. It is all in the sputum: a case of non-resolving pneumonia. BMJ Case Reports 2014;2014:bcr2014207843.

4. Özyurt S, Karataş M, Gümüş $A$, et al. Lipoid Pneumonia for Two Cases. Respir Case Rep 2015;4:160-4.

5. García Latorre R, Rodríguez Díaz R, Barrios Barreto D, Ayala Carbonero A, García Gómez-Muriel MI, Gorospe Sarasúa L. Exogenous Lipoid Pneumonia in Laryngectomy Patients: Radiological Findings. Arch Bronconeumol 2015;51:e36-9.

6. Kuroyama M, Kagawa H, Kitada S, Maekura R, Mori M, Hirano $\mathrm{H}$. Exogenous lipoid pneumonia caused by repeated sesame oil pulling: a report of two cases. BMC Pulmonary Medicine 2015;15:135.

7. Nguyen CD, Oh SS. A Case of Exogenous Lipoid Pneumonia. Respiratory Care March 2013;58:e23-e7.

8. Marchiori E, Zanetti G, Mano CM, Hochhegger B. Exogenous lipoid pneumonia. Clinical and radiological manifestations. Respir Med 2011;105:659-66.

9. Ali SK, Bhatti H. A fatty cough. Lung India 2016;33:537-9. 